ENTITA : Jurnal_Pendidikan_Ilmu_Pengetahuan_Sosial_dan_Ilmu-Ilmu_Sosial; Vol. 2 No.1, Juni 2020

ENTITA : Jurnal Pendidikan IImu Pengetahuan Sosial dan IImu-IImu Sosial http://ejournal.stainpamekasan.ac.id/index.php/entita

P-ISSN:2715-7555 E-ISSN:2716-1226

\title{
IImu Sosial dan Kemampuan Berpikir Kritis Matematis
}

\author{
Nurochim \\ UIN Syarif Hidayatullah Jakarta \\ nurochim@uinjkt.ac.id \\ Siti Ngaisah \\ CIC Riset dan Konsultan Sosial \\ sitingaisahcic@gmail.com
}

\section{Abstract}

In scientific studies there should be integration of science. Because with integration, knowledge will be comprehensively understood. Science integration should also be carried out to integrate social science and mathematics. The integration can be methodology integration, characteristic integration, and theoretical integration. The method used in this article is literature review. In this article it is revealed that social science consists of various disciplines related to human life. The disciplines that make up social science are History, Sociology, Anthropology, Economics, and Geography. The science discipline is based on theories developed empirically by figures based on time and space. Social science functions to form people who are aware of their rights and obligations. Therefore it is very important to develop mathematical critical thinking skills before studying social science. So that in studying social science, complete knowledge is obtained. Keywords: Social science, mathematics, Skills, think, critical.

Abstrak

Dalam kajian keilmuan hendaknya ada integrasi ilmu pengetahuan. Sebab dengan adanya integrasi, maka pengetahuan akan dipahami secara komprehensif. Integrasi ilmu hendaknya juga dilaksanakan untuk mengintegrasikan ilmu sosial dan ilmu matematika. Integrasi tersebut bisa integrasi metodologi, integrasi karakteristik, dan integrasi teoretik. Metode yang digunakan dalam artikel ini adalah kajian literatur. Dalam artikel ini diungkapkan bahwal ilmu sosial terdiri dari berbagai disiplin ilmu yang berkaitan dengan kehidupan manusia. Disiplin ilmu yang menyusun ilmu sosial adalah Sejarah, Sosiologi, Antropologi, Ekonomi, dan Geografi. Disiplin ilmu tersebut berdasar pada teori yang dikembangkan secara empiris oleh para tokoh berdasarkan ruang dan waktunya. IImu sosial berfungsi untuk membentuk manusia yang sadar akan hak dan kewajibannya. Oleh sebab itu sangat penting mengembangkan keterampilan berpikir kritis matematik sebelum mengkaji ilmu sosial. Sehingga dalam mengkaji ilmu sosial diperoleh pengetahuan yang utuh.

Kata Kunci: Ilmu social, matematika, keterampilan, berpikir, kritis

Received : 27 April 2020; Revised: 14 Mei 2020; Accepted: 29 Mei 2020

\section{(C) ENTITA : Jurnal Pendidikan IImu}

Pengetahuan Sosial dan IImu-IImu Sosial, http://doi.org/10.19105/ejpis

Institut Agama Islam Negeri Madura,

Indonesia 


\section{Pendahuluan}

Belajar akan tampak melalui perubahan tingkah laku yang disebabkan karena pengalaman (Lavasani, Afzali, \& Afzali, 2011). Belajar juga merupakan proses perubahan yang diperoleh melalui latihan (Shavelson, 2002). Lebih lanjut, Slameto mengungkapkan bahwa belajar merupakan suatu proses usaha yang dilakukan oleh individu untuk memperoleh suatu perubahan tingkah laku yang baru secara keseluruhan sebagai hasil pengalaman individu itu sendiri dalam interaksi dengan lingkungan (Slameto, 2003). Sutarti yang mengutip pendapat Winkel menambahkan bahwa belajar merupakan suatu aktivitas mental dan psikis yang berlangsung dalam interaksi yang aktif dengan lingkungan, yang menghasilkan perubahan-perubahan dalam pengetahuan, pemahaman, keterampilan dan nilai sikap (Sutarti, 2017).

Cara belajar yang paling efektif adalah dalam pembentukan penyelesaian masalah melalui kerja kelompok asalkan masalah tersebut disadari bersama. Belajar memerlukan pemahaman atas hal-hal yang dipelajari, sehingga diperoleh pengertian-pengertian. Belajar memerlukan latihan dan pengulangan, agar materi pelajaran yang dipelajari dapat dikuasai. Belajar harus disertai dengan keinginan dan kemauan yang kuat untuk mencapai tujuan. Belajar dianggap berhasil apabila si pelajar telah sanggup menerapkan dalam prakteknya.

Berdasarkan beberapa pendapat di atas dapat disimpulkan bahwa prinsip-prinsip belajar adalah dalam belajar, peserta didik harus terlibat aktif sehingga dapat memahami materi pelajaran sendiri. Adanya peningkatan minat dan bimbingan untuk mencapai tujuan belajar. Dalam belajar harus ada hubungan yang dinamis antara peserta didik dengan lingkungannya, sehingga dapat memahami materi pelajaran yang terkait dengan hal-hal yang kontekstual. Belajar perlu latihan dan pengulangan, sehingga pemahaman yang diperoleh selalu diingat oleh peserta didik. Belajar yang paling efektif adalah belajar yang berpikiran kritis, daripada hanya menghafal materi. 
Pendidikan IPS merupakan kelompok mata pelajaran yang dikaji dari tingkat SD, hingga di perguruam tinggi. Karakteristik Pendidikan IPS adalah relasi antar makhluk hidup. Dalam relasi tersebut biasanya terjadi konflik dan integrasi. Keterampilan dalam berpikir kritis penting dimiliki ketika akan mengkaji IPS. Sebab dengan memiliki keterampilan berpikir kritis maka, pemahaman akan ilmu IPS akan lengkap dan utuh.

Berbagai konflik di Indonesia semakin hari semakin meningkat, ditengah meningkatnya mutu pendidikan. Tidak hanya konflik munculnya berbagai berita bohong, isu, desas desus, dan gossip menjadikan ramai di tengah masifnya penggunaan gawai di masyarakat. Oleh sebab itu sangat penting dilaksanakan proses pendidikan yang saling terintegrasi, yang tidak hanya cerdas dalam angka tetapi memiliki kesalehan sosial dan spiritual.

Berdasarkan catatan Polri, sepanjang tahun 2018 terjadi 29 peristiwa konflik sosial. Kemudian, pada Januari-Juni 2019, Polri mencatat terjadi 26 peristiwa konflik sosial ("Polri: Penyelenggaraan Pilkada Berpotensi Timbulkan Konflik Sosial," n.d.). pada tahun 2019 jumlah konflik cenderung menurun, namun masih memiliki berbagai potensi konflik.

Penelitian-penelitian terkait upaya peningkatan kemampuan berpikir kritis menggunakan pembelajaran-pembelajaran inovatif sudah banyak dilakukan di Indonesia (Hendryawan, Yusuf, \& Wachyar, 2017). Apalagi yang saling mengaitkan antara matematika dan ilmu sosial. Padahal, dalam mengkaji ilmu sosial dibutuhkan keterampilan analisis dalam berelasi, sehingga diperoleh pemahaman yang komprehensif akan hak dan kewajiban.

\section{Metode Penelitian}

Metode yang digunakan dalam artikel ini adalah kajian literatur. Kajian literatur dilaksanakan dengan menganalisis sejumlah literatur yang relevan (Xiao \& Watson, 2019). Kajian literatur berfungsi untuk menemukan defisisi, pola, hubungan antar konsep-konsep, sehingga ditamukan pemahaman yang utuh. Dalam artikel ini berupaya untuk 
melaksanakan pendekatan multidisiplin (Shuck, 2011), dengan menguraikan bagaimana karakter pendidikan IPS dan kaitannya dengan keterampilan berpikir kritis matematis. Bidang IPS yang notabene masih dianggap sebagian orang sebagai mata pelajaran hafalan, kurang penting, namun pada hakekatnya pendidikan IPS tersusun atas berbagai subdisiplin. Subdisiplin Pendidikan IPS berbasis pada teori sosial yang kompleks terdiri dari berbagai paradigma dan konteks sosial. Paradigma dan konteks sosial itu justru paling dekat dengan kehidupan manusia. Pendidikan IPS berkaitan dengan relasi manusia dan lini kehidupannya, dengan mengkaji pendidikan IPS diharapkan manusia dapat memahami hak dan kewajibannya sehingga terciptak kehidupan yang selaras. Oleh karena itu penting dilekatkan dengan keterampilan kritis matematis.

\section{Hasil dan Pembahasan}

\section{Pendidikan IPS}

IImu Pengetahuan Sosial (IPS) merupakan salah satu mata pelajaran yang diberikan mulai dari SD/MI/SDLB sampai SMP/MTs/SMPLB termasuk SMK atau MAK. IPS mengkaji serangkaian peristiwa, fakta, konsep, dan generalisasi yang berkaitan dengan isu sosial. Pada jenjang SMP/MTs mata pelajaran IPS memuat materi Geografi, Sejarah, Sosiologi, dan Ekonomi. Melalui mata pelajaran IPS, peserta didik diarahkan untuk dapat menjadi warga negara Indonesia yang demokratis, dan bertanggung jawab, serta warga dunia yang cinta damai. Mata pelajaran IPS dirancang untuk mengembangkan pengetahuan, pemahaman, dan kemampuan analisis terhadap kondisi sosial masyarakat dalam kehidupan bermasyarakat yang dinamis (Endayani, 2017).

Pada dasarnya studi sosial lebih banyak menekankan pada studi hubungan manusia dengan lingkungnnya. Menurut Barr dalam Tanto Sukardi (2007:19) studi sosial adalah sebagai berikut: studi sosial pada hakekatnya merupakan kajian mengenai manusia dengan segala aspeknya dalam sistem hidup bermasyarakat. Kajian tersebut dilakukan dalam bentuk pembelajaran IPS di sekolah untuk mempersiapkan siswa 
menjadi warga negara yang baik, berdasarkan nilai-nilai kemasyarakatan yang berlaku dan perlu dikembangkan.

Menurut Sapriya IImu Pengetahuan Sosial (IPS) merupakan suatu mata pelajaran yang mengkaji serangkaian peristiwa, fakta, konsep, dan generalisasi yang berkaitan dengan isu sosial dan kewarganegaraan (Sapriya, 2016).

Bahan-bahan pembelajaran IPS diambil dari ilmu-ilmu sosial yang bertujuan untuk kepentingan kewarganegaraan. Materi dipilih secara selektif, sehingga relevan dan mampu membantu peserta didik memahami banyak manusia dan berbagai hal yang berkaitan dengan interrelasinya, baik yang terjadi pada masa lalu, masa kini, maupun masa datang. Mata pelajaran IPS disusun secara sistematis, komprehensif, dan terpadu dalam proses pembelajaran menuju kedewasaan dan keberhasilan dalam kehidupan di masyarakat. Dengan pendekatan tersebut diharapkan peserta didik akan memperoleh pemahaman yang lebih luas dan mendalam pada mata pelajaran IPS.

Mata pelajaran IPS bertujuan agar peserta didik memiliki kemampuan untuk mengenal konsep-konsep yang berkaitan dengan kehidupan masyarakat dan lingkungannya, memiliki kemampuan dasar untuk berpikir logis dan kritis, rasa ingin tahu, inkuiri, memecahkan masalah, dan keterampilan dalam kehidupan sosial, memiliki komitmen dan kesadaran terhadap nilai-nilai sosial dan kemanusiaan, memiliki kemampuan berkomunikasi, bekerjasama dan berkompetisi dalam masyarakat yang majemuk, di tingkat lokal, nasional, dan global.

IPS perlu difokuskan kepada upaya untuk menyediakan pengalaman belajar yang dapat membantu peserta didik dalam hal memahami bahwa lingkungan fisik menentukan bagaimana manusia hidup, memahami bagaimana manusia berusaha menyesuaikan dan menggunakan sumber lingkungan, memahami perubahan masyarakat, peserta didik harus mampu terlibat dalam perubahan sosial dan kebudayaan di dalam masyarakat, memahami dampak dari 
perkembangan saling ketergantungan antar manusia, dan memahami serta menghargai persamaan semua ras, agama, dan kebudayaan.

Ruang lingkup mata pelajaran IPS meliputi yang pertama manusia, tempat, dan lingkungan, yang ke dua waktu, keberlanjutan, dan perubahan, yang ketiga sistem sosial dan budaya, yang ke empat adalah perilaku ekonomi dan kesejahteraan.

Masing-masing mata pelajaran memiliki karakteristik yang berbedabeda, termasuk mata pelajaran IPS. Salah satu karakteristik mata pelajaran IPS pada Kurikulum Tingkat Satuan Pendidikan ditekankan bahwa: Substansi mata pelajaran IPS merupakan IPS terpadu, maka tuntutannya adalah guru IPS harus memahami dan menerapkan metodemetode pembelajaran terpadu. Karakteristik mata pelajaran IPS lainnya adalah bahwa masalah-masalah sosial kemasyarakatan sebagai obyek kajian IPS selalu berkembang terus menerus, maka sebagai guru mata pelajaran IPS dituntut untuk selalu mengikuti perkembangan tersebut agar apa yang diajarkannya merupakan hal-hal yang baru sehingga dapat mengikuti perkembangan zaman (Wulandari \& Firman, 2019).

Mata Pelajaran IPS dalam kurikulum 2013 revisi 2016 merupakan IPS Terpadu yang merupakan gabungan antara berbagai disiplin ilmu-ilmu sosial, yang terdiri atas beberapa bagian disiplin ilmu seperti Geografi, Sosiologi, Ekonomi, dan Sejarah, maka dalam pelaksanaannya tidak lagi terpisah-pisah melainkan menjadi satu kesatuan. Hal ini memberikan dampak terhadap guru yang mengajar di kelas. Guru harus menerapkan berbagai metode pembelajaran, menggunakan media yang relevan, memberikan informasi yang terbaru dan bermanfaat khususnya yang terkait dengan mata pelajaran IPS.

Berdasarkan beberapa pengertian yang sudah dikemukakan, maka dapat disimpulkan bahwa IPS terpadu merupakan mata pelajaran gabungan disiplin ilmu-ilmu sosial, yang objek kajiannya adalah peristiwa, fakta, konsep, dan generalisasi yang berkaitan dengan masalah-masalah sosial dan kewarganegaraan, dengan tujuan untuk membentuk peserta didik yang memiliki kemampuan untuk mengenal konsep-konsep yang 
berkaitan dengan kehidupan masyarakat dan lingkungannya, memiliki kemampuan dasar untuk berpikir logis dan kritis, rasa ingin tahu, inkuiri, memecahkan masalah, dan keterampilan dalam kehidupan sosial, memiliki komitmen dan kesadaran terhadap nilai-nilai sosial dan kemanusiaan, memiliki kemampuan berkomunikasi, bekerjasama dan berkompetisi dalam masyarakat yang majemuk, di tingkat lokal, nasional, dan global. IPS merupakan harapan untuk terbentuknya sikap warga negara yang diharapkan sesuai dengan tuntutan masyarakat.

\section{Motivasi Berprestasi, IPS, dan Keterampilan Berpikir Kritis}

Manusia sebagai makhluk sosial membutuhkan rasa sayang, pengakuan keberadaan, rasa ingin memiliki berbagai kebutuhan tersebut, manusia bekerja dan berusaha dengan sekuat tenaga untuk memenuhi keinginan itu. Pendidikan IPS berbasis pada mata pelajaran yang berkaitan dengan relasi sosial, namun dalam mempelajarai IPS diperlukan keterampilan berpikir kritis. Hal tersebut dikarenakan Teori-teori yang ada di lama kajian Sosial berkaitan dengan relasi kehidupan.

Menurut Kanfer mengungkapkan bahwa motivasi adalah kekuatan penggerak seseorang dalam organisasi, tingkat kekuatan yang dimiliki oleh seseorang, dan tingkat daya tahan yang dimiliki oleh sesorang (Heggestad \& Kanfer, 2000). Motivasi biasanya didefinisikan sebagai keinginan umum atau keinginan yang kuat yang menggerakkan manusia untuk mencapai sebuah tujuan (Boyle, Matthews, \& Saklofske, 2010).

Motivasi dapat diartikan sebagai berikut: (1) Dorongan yang timbul pada diri seseorang, secara disadari atau tidak disadari, untuk melakukan tindakan dengan tujuan tertentu; (2) Usaha-usaha yang dapat menyebabkan seseorang atau kelompok orang tertentu tergerak melakukan sesuatu karena ingin mencapai tujuan yang ingin dicapai. Motivasi sebagai serangkaian usaha menyediakan kondisi-kondisi tertentu, sehingga seseorang ingin melakukan sesuatu dan mencapai sebuah tujuan (Pinder, 2008). 
Motivasi berprestasi merupakan salah satu faktor primer dalam menentukan keberhasilan peserta didik. Hal ini merupakan pendorong yang digerakkan oleh kesadaran untuk melakukan tindakan.

Kaplan mengungkapkan bahwa individu yang memiliki dorongan berprestasi yang tinggi memiliki ciri sebagai berikut memiliki keinginan yang kuat untuk melakukan hal-hal dengan lebih baik, memiliki tanggung jawab pribadi dalam menyelesaikan berbagai masalah, memilih pekerjaan dengan resiko sedang dan mendapatkan umpan balik dengan segera, dan menentukan tujuan yang hendak dicapai (Kaplan, 2008).

Dalam hal ini motivasi berprestasi sebagai suatu usaha untuk meningkatkan atau mempertahankan kecakapan pribadi setinggi mungkin dalam segala aktivitas dengan suatu ukuran keunggulan digunakan sebagai pembanding. Orang yang mempunyai motivasi berprestasi yang tinggi atau yang mempunyai motif untuk mendekat yang tinggi, jika dihadapkan dengan suatu tugas yang harus dilakukan dalam situasi yang memaksa, akan menunjukkan motivasi yang terkuat jika kesukaran tugas itu sedang, jika dihadapkan pada tugas yang lebih sukar atau lebih mudah, motivasi yang ditunjukkan akan lebih lemah.

Motivasi yang dimiliki siswa, dalam hal ini motivasi berprestasi akan menentukan upaya siswa dalam memiliki prestasi dalam bidang pendidikan. Motivasi berprestasi sangat dibutuhkan dalam proses pembelajaran. Motivasi berperan penting dalam setiap pencapaian tujuan seseorang, termasuk siswa. Orang yang mempunyai motivasi berprestasi yang tinggi, mempunyai ciri-ciri sebagai berikut: a)mempunyai tanggung jawab pribadi, b) Memiliki tugas yang moderat, c) memperhatikan umpan balik tentang perbuatannya. Siswa yang mempunyai motivasi berprestasi akan melakukan tugas sekolah atau bertanggung jawab terhadap pekerjaannya. siswa yang bertanggung jawab terhadap pekerjaan akan puas dengan hasil pekerjaan karena merupakan hasil usahanya sendiri. Siswa akan menetapkan tujuan yang akan dicapai, tujuan itu lebih tinggi dari tujuan sendiri (internal) atau lebih tinggi dengan tujuan yang dicapai oleh orang lain (eksternal). 
Siswa yang bermotivasi berprestasi tinggi, gigih dan giat mencari cara yang kreatif untuk menyelesaikan tugas dan tanggung jawabnya. Siswa yang mempunyai cita-cita akan berusaha sebaik-baiknya dalam tugas, tekun dan ulet, serta pantang menyerah ketika bertugas. Siswa yang memiliki motivasi berprestasi yang tinggi akan memilih tugas yang moderat yaitu memiliki tugas yang tidak terlalu sukar dan tidak terlalu mudah. Siswa dengan motivasi berpretasi yang tinggi, yang harus mengerjakan tugas yang sangat sukar, akan tetapi mengerjakan tugas tersebut dengan membagi tugas menjadi beberapa bagian, yang tiap bagian lebih mudah menyelesaikanya. Siswa yang mempunyai motivasi berprestasi yang tinggi akan melakukan semua tugas sebaik mungkin dan tidak ada kegiatan lupa di kerjakan. Siswa akan mengadakan atisipasi untuk menghindari kegagalan atau kesulitan yang mungkin terjadi. Antisipasi dapat dilakukan siswa dengan menyiapkan semua keperluan atau peralatan sebelum melaksanakan tugas.

Motivasi berprestasi merupakan kebutuhan untuk melakukan perkerjaan yang lebih baik dari sebelumnya, dan selalu berkeinginan mencapai prestasi yang lebih tinggi. Siswa diharapkan menyukai tantangan dan mampu memecahkan permasalahan dalam pekerjaannya dengan lebih baik yang pada akhirnya dapat mendukung tercapainya prestasi kerja secara memuaskan.

Dengan mencapai sebuah prestasi maka seseorang akan mendapatkan rasa hormat, atau imbalan lainnya. Motivasi berprestasi yang dimiliki siswa harus ditumbuhkan dari dalam diri individu yang bersangkutan dan didukung oleh lingkungan kerja. Hal tersebut dikarenakan motivasi berprestasi yang ditumbuhkan dari dalam diri individu akan membentuk kekuatan diri bagi individu. Selain itu, apabila situasi lingkungan kerja turut mendukung, maka pencapaian kinerja akan lebih mudah tercapai.

Kemampuan berpikir tingkat tinggi pada jenis: pemahaman konsep (conceptual understanding), pemecahan masalah (problem solving), penalaran dan pembuktian (reasoning and proof), komunikasi 
(communication), koneksi (connection), dan representasi (representation) (Abdullah, 2013). Kemmapuan berpikir tingkat tinggi ini, berkaitan erat dengan kajian-kajian Pendidikan IPS yang terdiri dari berbagai disiplin ilmum kehidupan manusia.

Kemampuan berpikir kritis secara literature lahir dari dua disiplin ilmu yakni filsafat dan psikologi (Lai, 2011). Yang selanjutnya kemampuan berpikir kritis berdiri di ranah pendidikan. Dengan mengembangkan kemampuan berpikir kritis, maka akan menemukan bukti untuk "menghakimi" pemahaman yang dimiliki oleh manusia (Keynes, 2008). Contoh dengan berpikir kritis maka dapat mempertimbangkan apakah perbuatan tersebut merugikan diri sendiri dan orang lain atau tidak.

Keterampilan berpikir kritis seharusnya menjadi nadi dalam proses pembelajaran di sekolah (Firdaus, Kailani, Bakar, \& Bakry, 2015). Kemampuan berpikir kritis juga meningkatkan mutu karakter siswa (Palinussa, 2013). Dengan kemampuan berpikir kritis maka dapat meningkatkan kinerja akademik siswa (Changwong, Sukkamart, \& Sisan, 2018). Dengan demikian setiap mengkaji suatu bidang ilmu maka kemampuan berpikir kritis sangat penting dikembangkan sebagai dasar dalam mengkaji.

\section{Kesimpulan}

Karakteristik Pendidikan IPS yang multidisiplin, namun sangat erat dengan relasi kehidupan manusia, sangat penting dikaji dari level Sekolah Dasar hingga Perguruan Tinggi. Pendidikan IPS yang tersusun atas berbagai disiplin ilmu sosial membutuhkan keterampilan analisis kritis, sehingga Pendidikan IPS menjadi mata pelajaran yang dapat mewujudkan manusia yang memiliki hak dan tanggung jawab yang berimbang. Keterampilan analisis kritis tersebut dibutuhkan berbekal kemampuan analisis kritis matematis. Oleh sebab itu Keterampilan kritis matematis sangat penting dikembangkan disetiap satuan pendidikan disesuaikan dengan jenjang usia dan pendidikan. 


\section{Daftar Pustaka}

Abdullah, I. H. (2013). Berpikir Kritis Matematik. Jurnal Matematika Dan Pendidikan Matematika, 2(1), 66-75. Retrieved from http://www.ejournal.unkhair.ac.id/index.php/deltapi/article/view/100

Boyle, G. J., Matthews, G., \& Saklofske, D. H. (2010). The Handbook of Personality Theory and Assessment. Los Angeles, Calif.: SAGE Publications.

Changwong, K., Sukkamart, A., \& Sisan, B. (2018). Critical thinking skill development: Analysis of a new learning management model for Thai high schools. Journal of International Studies, 11(2), 37-48. https://doi.org/10.14254/2071-8330.2018/11-2/3

Endayani, H. (2017). Pengembangan Materi Ajar Ilmu Pengetahuan Sosial. Ijtimaiyah: Jurnal Program Studi Pendidikan IImu Pengetahuan Sosial, 1(1), 92-110. Retrieved from http://jurnal.uinsu.ac.id/index.php/ijtimaiyah/article/download/1158/922

Firdaus, Kailani, I., Bakar, M. N. Bin, \& Bakry. (2015). Developing Critical Thinking Skills of Studens in Mathematics Learning. Journal of Education and Learning, 9(3), 226-236. https://doi.org/10.1007/s00365-013-9198-y

Heggestad, E. D., \& Kanfer, R. (2000). Individual Differences in Trait Motivation: Development of the Motivational Trait Questionnaire. International Journal of Educational Research, 33(7-8), 751-776. https://doi.org/10.1016/S0883-0355(00)00049-5

Hendryawan, S., Yusuf, Y., \& Wachyar, T. Y. (2017). Analisis Kemampuan Berfikir Kritis Matematis Siswa SMP Tingkat Rendah Pada Pembelajaran Berbasis Masalah dengan Green's Motivational Strategies. Aksioma, 8(2), 50. https://doi.org/10.26877/aks.v8i2.1744

Kaplan, A. (2008). Achievement Motivation. PSYCHOLOGY OF CLASSROOM LEARNING, https://doi.org/10.1007/springerreference_223384

Keynes, M. (2008). Skills for OU Study Thinking Critically. United Kingdom: Open University Press.

Lai, E. R. (2011). Critical Thingking: A Literature Review (Vol. 35). https://doi.org/10.1046/j.1537-2995.1995.35395184278.x

Lavasani, M. G., Afzali, L., \& Afzali, F. (2011). Cooperative Learning and Social Skills. Cypriot Journal of Educational Sciences, 4(1), 1861993.

Palinussa, A. L. (2013). Students' critical mathematical thinking skills and character: IndoMS.J.M.E, 4(1), 75-94.

Pinder, C. C. (2008). Work Motivation in Organizational Behavior. Retrieved

from

http://proxy.uqtr.ca/login.cgi?action=login\&u=uqtr\&db=ebsco\&ezurl=ht tp://search.ebscohost.com/login.aspx?direct=true \&scope =site $\& \mathrm{db}=\mathrm{nle}$ bk\&db=nlabk\&AN=815126

Polri: Penyelenggaraan Pilkada Berpotensi Timbulkan Konflik Sosial. (n.d.). Retrieved December 28, 2019, from https://nasional.kompas.com/read/2019/12/19/11135851/polripenyelenggaraan-pilkada-berpotensi-timbulkan-konflik-sosial 
Sapriya. (2016). Pendidikan IPS. Retrieved from http://opac.library.um.ac.id/oaipmh/../index.php?s_data=bp_buku\&s_fi eld $=0 \&$ mod $=b \& c a t=3 \& i d=55589$

Shavelson, R. J. (2002). Lee J. Cronbach (1916-2001): Obituary. American Psychologist, Vol. 57, pp. 360-361. https://doi.org/10.1037/0003-066x.57.5.360

Shuck, B. (2011). Integrative literature review: Four emerging perspectives of employee engagement: An integrative literature review. Human Resource Development Review, 10(3), 304-328. https://doi.org/10.1177/1534484311410840

Slameto. (2003). Belajar Dan Faktor-Faktor Yang Mempengaruhinya. Retrieved from http://opac.library.um.ac.id/oaipmh/../index.php?s_data=bp_buku\&s_fi eld $=0 \&$ mod $=b \& c a t=3 \& i d=29615$

Sutarti, T. (2017). Efforts to Increase Students Reading Interest on Educational Reference Through Classical Guidance and Counseling Experiential Learning Model. JETL (Journal Of Education, Teaching and Learning), 2(1), 118. https://doi.org/10.26737/jetl.v2i1.152

Wulandari, R., \& Firman. (2019). Sarana Dan Sumber Belajar dalam Pembelajaran IPS di Sekolah Dasar. (January).

Xiao, Y., \& Watson, M. (2019). Guidance on Conducting a Systematic Literature Review. Journal of Planning Education and Research, 39(1), 93-112. https://doi.org/10.1177/0739456X17723971 